\title{
SOLIDARITY \\ A LOOK AT THE LITERATURE OF A SOCIAL MOVEMENT, 1980-1989
}

\section{Grace Cardwell}

"The defense of our rights and our dignity, as well as efforts never to let ourselves to be overcome by the feeling of hatred - this is the road we have chosen."

\section{-Lech Walesa, I983}

After the end of the Second World War, the two largest superpowers, the United States and the Soviet Union, plunged into the Cold War, an ideological battle that would last for the better part of the next four decades. The clash of these nations would not be contained for long, however, eventually manifesting itself in all corners of the globe. One particular example of Cold War stress was in the Eastern bloc, the so-called Soviet "sphere of influence." In the years following the war, economic conditions worsened throughout the world, which, in turn, shed a particularly influential light on Eastern Europe. The Soviet Union's hold on the Eastern bloc began to fade as citizens (most notably in Hungary, Czechoslovakia, and Poland) rose to action against governments they felt no longer effectively represented them. In Poland, citizens saw how the economic policies of the Communist Party, which had once promised them a better life, had begun to fail. This united them behind a movement that would bring foundational, lasting change; it would be called Solidarity, a word that meant consensus, agreement, and harmony. The Solidarity Movement in Poland focused on creating change through a strong and meaningful unity. It involved a collective struggle for, as Lech Wałęsa, the movement's leader, called it, "the repair of the republic."

Solidarity emerged due to the gradual decline of living standards in an increasingly stagnating economy. When examining the history of the Cold War, the Eastern bloc, Poland, or social change in general, scholars around the world cite it as one of the 


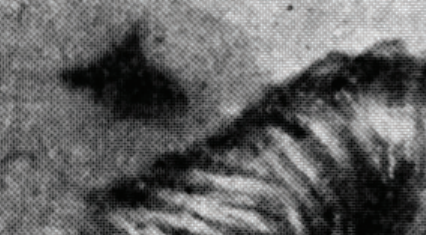

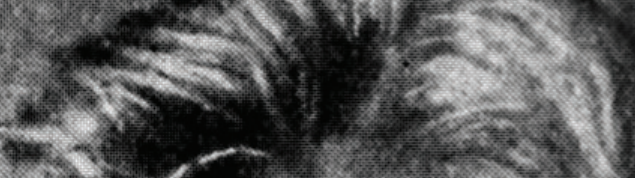
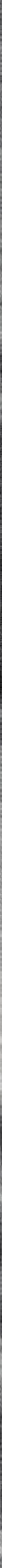
most foundational, successful social movements. As American historian Lawrence Weschler stated, "it is the latest proof that the aspirations and needs of working people cannot be permanently repressed even by the most authoritarian system." While there is a general consensus of this throughout Cold War historiography, opinions of the reasons for Solidarity's success changed significantly over the course of its existence. During the early years of the movement, the objective of Solidarity was written almost exclusively in the context of workers' rights. Much of the historical narrative focused solely on how Communism had affected the daily lives of the working class, and how their strength and determination evolved into the Solidarity Movement. It chronicled how Poland's workers, unhappy with the present economic conditions, demanded reform from a government that was failing them.

Less than a decade after Solidarity was founded, however, the historiography of the movement began to touch on a different component, perhaps the key to its lasting success. Historiography from the later years seemed to concur that the real triumphs of Solidarity were due to the combination of workers, intellectuals, professionals, and the Catholic Church. Indeed, Poland's workers were strongly united and faithfully committed to bringing economic reform, but what made Solidarity so revolutionary was the collective effort of several different social groups. This is what would bring about the kind of repair that

I. Lawrence Weschler, Solidarity, Poland in the Season of its Passion (New York: Simon and Schuster, 1982), xiii.
Lech Wałęsa envisioned. After 1983, scholar's opinions on the success of Solidarity took a noticeable shift: they argue that what was so revolutionary about themovementwasthatitblurred the line between Poland's social groups. This provided for a powerful combination that the Communist Party could only ignore for so long.

The historiography of the Solidary movement remains today an ongoing and vibrant enterprise. When we look back on the early years, however, it becomes clear that during the years before the end of communism in Poland, commentators shifted from an explanation of the movement solidly rooted in Solidarity as an economic struggle to one, in the later years, that stressed the social nature of the movement as a collaboration between workers, the intelligentsia, and the Church.

\section{CONDITIONS IN POLAND}

One of the most interesting facets of the Cold War was how it managed to apply a relatively simple concept - the competition between two differing ideologies -to the global stage. Nations around the world watched as the political battle spread to their economic, social, and cultural spheres. After World War II, much of Eastern Europe had been integrated into the Soviet sphere of influence through a network of treaties and agreements, including the Warsaw Treaty Organization. ${ }^{2}$ These links were made to tie Eastern Europe to the Soviet Union. After all, the importance of ideological allies during this time could not be overemphasized. But in time,

2. R. J. Crampton, Eastern Europe in the Twentieth Century (London: Routledge, I994), 240. 
citizens grew frustrated with the Communist system. This eventually brought the Soviet sphere to global prominence as the Soviet Union's hold on their Eastern bloc countries began to slip away. ${ }^{3}$ As the Cold War continued, the challenges that Communism faced there only increased, making Eastern Europe one of the most influential arenas for the Cold War "battles" to unfold.

The resistance that began to stir in Poland would eventually evolve into one of the most powerful social movements of the age, but conditions there were not always so complex. In fact, during the r 960 s and into the I970s, circumstances were relatively functional. In the years leading up to Solidarity, Edward Gierek, the First Secretary of the Communist Party, led Poland. Through his initial economic reform strategies, Gierek asked the people of Poland to believe that the Communist Party had turned over a new leaf. The Party even adopted a new slogan: "moral-political unity of the nation," hoping to reflect these changes. ${ }^{4}$ The Communist Party also instituted a number of social reforms, including a relaxation of censorship, an attempted reconciliation with the Catholic Church and the Polish intelligentsia, and a foreswearing of the use of violence against Polish citizens. ${ }^{5}$ Gierek, the son of a coal-miner, was classified as a "common man." His familiar speech and respectful manner were a breath of fresh air to Poles,

3. Crampton, Eastern Europe, 24I.

4. Keith John Lepak, Prelude to Solidarity: Poland and the Politics of the Gierek Regime (New York:

Columbia University Press, 1998), 47.

5. Ben Slay, The Polish Economy: Crisis, Reform, and Transition (Princeton: Princeton University Press, 1994), 36 . who were all too familiar with the unfriendly and detached Wladyslaw Gomulka, Gierek's predecessor. ${ }^{6}$

In the economic arena, Gierek introduced what he called the "New Development Strategy," which he said would achieve success "by taking advantage of Poland's new position in the international arena." The keys to the New Development Strategy included obtaining Western imports of investment goods, which would modernize Polish industry and agriculture, and increasing the availability of consumer goods, which would improve living standards and work incentives. ${ }^{8}$ When Gierek's New Development Strategy was introduced, not only did the national economy see increased production of consumer goods and new technologies, citizens saw both their wages and opportunities as Polish citizens increase. ${ }^{9}$ Edward Gierek's rule thus began with a feeling of optimism, as he genuinely sought not only to improve the Polish economy, but also to create a thriving Soviet-type society. ${ }^{10}$ The beginning of Poland's economic decline, however, resulted from the gradual mishandling and miscommunication of policies by the Gierek administration. Gierek sought to make Poland into the ideal Soviet society, and he was initially successful with reforms that seemed

6. Keith John Lepak, Prelude to Solidarity: Poland and the Politics of the Gierek Regime (New York:

Columbia University Press, I998), 52.

7. Slay, The Polish Economy, 37.

8. Slay, The Polish Economy, 37.

9. Michael D. Kennedy, Professionals, Power and Solidarity in Poland: A Critical Sociology of Soviettype Society, (Cambridge: Cambridge University Press, 199I), 38.

Io. Anita Prazmowska, A History of Poland, (New York: Palgrave Macmillan, 2004), 203. 
to center on the people themselves. ${ }^{\text {II }}$ But before long, Poland erupted into precisely the type of chaos that Gierek had desperately tried to avoid. His popularity with the people plummeted as the New Development Strategy began falter, and the situation only worsened in the years to come.

\section{THE EMERGENCE OF SOLIDARITY}

This gradual, decade-long collapse of the Polish economy in the I970s laid the groundwork for the beginnings of the Solidarity Movement in Poland. It began with a strain on the worldwide economy, as the 1973 Oil Crisis hit the majority of the world's countries hard. This clinch significantly undermined the West's willingness and capacity to buy goods and invest stock in Poland, a key facet of Gierek's strategy for reform. ${ }^{12}$ Additionally, Poland's efforts to match the technological innovations of the West (and convince them that Poland was a viable investment) had accumulated a huge amount of national debt with no feasible solution for paying it off.

Furthermore, bad harvests in the early ig7os halted agricultural production, creating a food shortage that would only deepen Poland's downward spiral. ${ }^{13}$ Inflation, on the rise, reached triple digits by I979, as investment capital became permanently frozen in unfinished projects. ${ }^{\mathrm{I}}$ The Polish government sought to solve foreign indebtedness via price hikes, but these, especially in meat, a staple of the Polish diet, further

\footnotetext{
II. Kennedy, Professionals, Power, 39.

I2. Prazmowska, A History, 204.

13. Slay, The Polish Economy, 44.

I4. Slay, The Polish Economy, 49.
}

angered citizens. This increased their frustrations and led them to strike. ${ }^{15}$

To be a citizen in Poland in the late ig7os meant a constant struggle against unfavorable economic odds. Food shortages were prevalent, accompanied by a sharp decrease in national production, which affected income. There was also an increasing presence of "hidden inflation," or the repackaging of existing products as new ones. ${ }^{16}$ Even worse, this was all in the aftermath of the promise of a society that would prosper. These economic tensions and rising frustrations of the people meant the return of political problems. Instead of initiating radical reforms, as conditions took a turn for the worse, Gierek and the Communist Party moved to recentralize economic authority after 1976. ${ }^{17}$ Poland had reached the tipping point. Workers, a central component of any nation's economy, grew frustrated as the situation worsened. They found themselves unable to purchase the food on the shelves, if there was food there at all. Many realized that what Poland really needed was not more Communist reforms, nor help from the West, but action from within. With growing numbers and increased confidence, strikes began to pop up at many coastal (and eventually inland) locations. The people rallied behind Lech Wałęsa, a common citizen recently fired from his factory job as an electrician. Solidarity saw rapidly increasing success and participation over the next few months. Five hundred days following the founding, it had Io million

I5. Prazmowska, A History, 204.
I6. Slay, The Polish Economy, 45.
I7. Slay, The Polish Economy, 46. 
members, a quarter of the country's population. ${ }^{18}$ The accomplishments they enjoyed in the first few months contributed to the movement's future strength and success. It became the first independent trade union in the Soviet bloc, and it would eventually transform into a full on revolutionary movement. ${ }^{19}$

\section{LITERATURE FROM}

\section{SOLIDARITY'S EARLY YEARS (1980-1983)}

Solidarity was a movement unlike anything Poland or its people had ever experienced. Some of the older participants remembered the "Polish October" of 1956, an early example in which young, educated Poles rose up and sought reforms to the Stalinist model of socialism. ${ }^{20}$ While many more remembered the Hungarian Uprising and the Prague Spring in Czechoslovakia, the reform movements had similar goals. These earlier incidents from around the Eastern bloc would come to define their experiences in the pre-Solidarity years. ${ }^{2 \mathrm{~T}}$ With Solidarity attracting such widespread participation and experiencing such a large degree of initial success, many contemporary scholars began recording this social revolution in writing. They recognized it as the movement that would transform

\footnotetext{
I8. "Solidarity, Gdansk, Poland," Gdansk Life Poland Travel Guide, accessed October 24, 20II, http://www.gdansk-life.com/poland/solidarity. I9. "Solidarity, Gdansk, Poland," Gdansk Life Poland Travel Guide, accessed October 24, 20II, http://www.gdansk-life.com/poland/solidarity. 20. Bartosz Kaliski, "Solidarity, I980-r:The Second Vistula Miracle?" in Revolution and Resistance in Eastern Europe: Challenges to Communist Rule, ed. Kevin McDermott and Matthew Stibbe (Oxford: Berg, 2006), I20. 2I. Kaliski, "Solidarity, I980-I," I2I.
}

Poland and define their generation. Scholars writing about Solidarity in its early years tended to describe it as a surge of the working class, whose members sought reforms to the system of government that had been failing them over the past decade or so. When writing their accounts, many Polish and Western scholars alike approached the situation using personal accounts of the participating men and women. They discussed both the grievances that had brought them to Solidarity and what they hoped would come of it. These early sources contain two main components: the economic nature of the Solidarity campaign and the valiant, courageous nature of the workers. Even once the fight turned political, these early sources concur that Solidarity had its roots in the basic desire of the workers for fair prices, adequate living conditions, and a stable work environment.

Historians of Solidarity's early years often included conversations with members of the Polish working class, and they clearly argue for an understanding of the movement as a workers' revolution. Jean-Yves Potel, a French writer and revolutionary traveling in Poland at the time, composed his book, The Summer Before the Frost, based on conversations with these working-class individuals. It is clear through his accounts that workers did not have as much concern (if any at all) for the political implications of the movement as they did for whether or not their paycheck would allow them enough money to buy food. "We didn't understand why," Potel recounted from his conversation with a working class woman. "Since they were increasing 
prices, they should have increased wages as well., ${ }_{22}$ The Solidarity Movement, for the struggling workers, was a reaction to how the current system of government in Poland had been the cause for their economic strife. Very few workers sought any sort of ideological gains. ${ }^{23}$ From what Potel gathered through talking with the workers who started it all, the desire was for control of the fruits of their labor. "That is what every Solidarity traded unionist wanted," Potel opined. "That was what they were hoping for." ${ }^{24}$

While for Potel and other early scholars the strength and unity of the working class force was the main factor in the success of the Solidarity Movement, Lawrence Weschler, an American writer and political scientist, cited Solidarity's influence on similar American labor movements. He began with a sympathetic poem, glorifying the power of workers in Poland at the time:

When the union's inspiration throughthe workers' blood shall run, There can be no power greater anywhere beneath the sun. In our hands is placed a power greater than their hoarded gold, greater than the might of armies, magnified a thousand fold. ${ }^{25}$

The poem suggests that workers in Poland recognized an important component of their fight: that by banding together they would not only be effective, but a mighty and unavoidable force. Weschler, like

22. Jean Yves Potel, The Summer before the Frost: Solidarity in Poland (London: Pluto, 1982), I6.

23. Potel, Summer, 80.

24. Potel, Summer, 84.

25. Weschler, Poland in the Season, xii.
Potel, also wrote about the economic roots of the campaign, asserting that: "[Poland's] deterioration stems in part from the economic effects of all the recent political turbulence...but it is more generally a result of the cumulative damage to the economy of the thirty-five years of mismanagement." ${ }^{26}$ From conversations with many members of the working class, Weschler asserted that it is clear that the workers were the ones with the most to gain from an upheaval. In one particular instance, he spoke with a farmer, who told Weschler that he "must wait for up to three weeks to rent a grass cutter or a harvester from the government. 'By then,' he says, 'the harvest is over."' For Weschler, it was the workers and farmers of Poland, increasingly unhappy with the current system, who banded together and were able to achieve reform. The changes they sought were not necessarily political, but due to the fact that they could no longer make a living, receive a promotion, or, in many cases, even eat under the current conditions. Another consistent theme from early accounts of Solidarity is the portrayal of the workers as valiant pursuers of freedom and liberty - as underdogs in a noble fight against years of injustice. Timothy Garton Ash, a British historian studying in Poland at the time, wrote his account of the Solidarity Movement in 1982. Much can be said about Ash's account of Solidarity before even flipping through the body of the work. Its title, Revolution in Poland, denotes insurrection and insurgence. Through his descriptions

26. Weschler, Poland in the Season, 9.

27. Weschler, Poland in the Season, 13. 
of Solidarity, he offered the reader a thorough portrayal of not only what the workers sought from the government, but also who they were and why their character was the essential component that led to Solidarity's success. In his visit to the Lenin shipyard where Solidarity first emerged, he noted:

What I remember most vividly from the Lenin Shipyard is not the leaders, Lech Wałęsa or Andrez Gwiazda, but the figure of one ordinary striker. He was in his mid-twenties, lithe, with short-cropped hair and piercing eyes. It was young men like him who would come into their own in Solidarity, and give the moment its extraordinary youthful energy and fearlessness. ${ }^{28}$

For Ash it was the workers, seemingly with no political aims, who were the noble ones. They deserved credit for Solidarity's triumphs.

As Ash chronicled Solidarity's progression, he described advances like the Gdansk Agreement, which increased civil liberties in Poland, as "a tremendous victory for the workers." ${ }^{29}$ In his accounts of negotiations with the Communist Party, he consistently noted that the workers, persistent and unrelenting, refused to accept smaller reforms as concessions in place of the larger, sweeping reforms they wanted..$^{\circ}$ The workers that made up Solidarity, Ash asserted, had to wait patiently for what they wanted, and did so nobly. Through their efforts, they were the ones to

28. Timothy Garton Ash, The Polish Revolution, Solidarity 1980-2 (London: Cape, 1983), 37 . 29. Garton Ash, The Polish Revolution, 68. 30. Garton Ash, The Polish Revolution, I35. enact the lasting change that came to Poland. He demanded that the story of the workers be heard: "In the face of economic recession and the threat of nuclear war, young Polish workers, who had lived their whole lives under Communism, were daubing on a crane in the Lenin Shipyard the words 'Man is born and lives free."'

But these workers were not only courageous and determined; they were organized, smart, and disciplined. Alex Pravda, a British historian specializing in the international dimension of Eastern European politics, wrote an essay, also in I982, called "Poland i980: From "Premature Consumerism' to Labour Solidarity." Here, he argued that for the first time in a communist state, "workers' self assertiveness went beyond violent, fragmented and short-lived protest to emerge as a well-organized solitary labor movement. It was a selfmobilized workers' protest and a rare instance of authentic working-class spontaneity." ${ }^{22}$ Pravda, like many of his fellow historians writing at the time, attributed Solidarity to workers' intuition and willpower after years of persistent injustice. Pravda depicted the workers' journey to Solidarity as a forever deepening spiral, beginning with a gradual decline, but quickly heightening to its climax in 1980. ${ }^{33}$ For Pravda, the success was indeed about the workers, but there is another level added by Pravda to Ash's portrayal of them - one that was not only about a relentless fight, but also an organized and purposeful unity.

Pravda shares this viewpoint

3I. Garton Ash, The Polish Revolution, 338. 32. Alex Pravda, "Poland I980: From 'Premature Consumerism' to Labour Solidarity," Soviet

Studies 34, no. 2 (April I, 1982): 167.

33. Pravda, "Poland ı980," I68. 
with fellow Polish scholar Wojciech Modzelewski, who argued that an invaluable contribution of the workers was the non-violent nature of their campaign. Modzelewski, with a similar, but perhaps less assertive tone as Ash, portrayed the workforce who led Solidarity as the underdog, fighting against the odds for an honest cause. The main assertion of his article was that in order to pull off such a massively successful protest, but still maintain its non-violent nature, it required "a great deal of discipline, organization, preparation, supervision, and leadership," all of which can be attributed to the Solidarity Movement. ${ }^{34}$ The nonviolent way in which the workers chose to act not only avoided disturbances and violence, but also resulted in a constructive attempt at reforming the system. ${ }^{35}$ Modzelewski and his contemporary authors saw these workers as Solidarity personified. They were the ones that fought against the economic injustice that was plaguing Poland, and had fought with valor. Solidarity, for these early writers, had emerged from the hearts of the people.

\section{LITERATURE FROM}

\section{SOLIDARITY'S LATER YEARS (1984-1989)}

As the Cold War continued, so did Solidarity. The patient Polish citizens watched as the democratic reforms they desired became reality. The movement required sustained effort and determination from the workers, this much is certain. But, as the literature about Solidarity expanded

34. Wojciech Modzelewski, "Non-Violence and the Strike Movements in Poland." Journal of Peace Research I9, no. 2 (January I, I982): IIO. 35. Modzelewski, "Non-Violence," II2. into the later half of the I980s, a different examination of it emerged. The workers were determined and their effort was valiant, but they also had the help of numerous other groups in their struggle for reform. As scholars continued to write about Solidarity, they began to shed new light on other groups that had a large and influential role to play in the movement's success. They include the intellectuals, professionals, and the Catholic Church. The intellectual class in Poland, often referred to as the intelligentsia, had been involved in reform politics in Poland since the early r95os. Up until around 1970, the Polish Intellectuals Revisionist Group had attempted to reform the political system by appealing directly to the Party, advocating for a relaxation of censorship and greater intellectual freedom. After decades of frustration and precious few results, they threw their support behind the workers. Kazimierz Poznanski, a professor born in Germany but raised in Poland, commented on this in his article, "Economic Adjustment and Political Forces: Poland since 1970." $\mathrm{He}$ argued that the intelligentsia initially supported the workers through financial and legal assistance, but eventually became further involved with the workers' cause, encouraging political activism among them..$^{36}$ According to Poznanski, the intellectual class in Poland also had much to gain from reform to the system, although their agenda was more political than economic in scope.

The intelligentsia in Poland had

36. Kazimierz Poznanski, "Economic

Adjustment and Political Forces: Poland since 1970," International Organization 40, no. 2 (April I, I986): 47 I. 
always been an adversary of the Communist party, but in contrast to their previous efforts, their involvement with the workers of 1980 , broadened Solidarity's foundation and increased its influence. "In previous protests," claimed Adam Bromke, a Polish political scientist, "the students and the intelligentsia received no support from the workers and barely even worked behind the scenes, essentially playing no role., ${ }_{37}$ But Solidarity brought about the successful joining of these groups, largely because Solidarity's workers had been well educated under the Gierek administration. The workers themselves felt better informed, increasing their confidence and effectively closing the gap between the working and intellectual classes..$^{38}$ This combination of the two groups-more specifically the blending of their economic and political motives --led to a higher degree of cooperation, setting Poland apart from other Eastern bloc reform efforts. With the influence of the intellectuals, Bromke argued, the working class realized that in addition to their economic desires, they could gain from political reform. ${ }^{39}$ This blending of ideas only strengthened their cause.

The Polish intelligentsia was just one of the well-organized social groups that was increasingly outside party control. $4^{\circ}$ In the later I980s, scholars from a variety of fields began to write about the Solidarity Movement. Michael D. Kennedy, a sociologist, published an article arguing for the

37. Adam Bromke, Eastern Europe in the aftermath of Solidarity (Boulder: East European Monographs, 1985), 53 .

38. Bromke, Eastern Europe, 53.

39. Bromke, Eastern Europe, II2.

40. Poznanski, "Economic Adjustment," 456. vital participation of professionals in the Solidarity Movement, specifically with regard to the involvement of engineers. Engineers and other professional workers in Poland, who previously enjoyed relatively elevated status, threw their support behind the workers after the economy in Poland began spiraling downward. ${ }^{4}$ Because of the decline, citizens were no longer able to reap the benefits of technological advancement, and thus engineers began to lose their importance. Thus, engineers decided that aligning with the working class, which was gaining strength and significance, would supplement production and their livelihood. For Kennedy, the cooperation between professionals and workers, though unlikely in a Soviet style society, was one of the reasons Solidarity became such a successful social transformation..$^{42}$

Not only was maintaining contact with workers essential to production for professionals, but as the movement gained strength, Polish engineers realized how much there was to gain from economic and political reform of the system. Kennedy explained why the participation of professionals in this social movement was such a key element to its success:

In Soviet-type societies, engineers and other professionals constitute the pivotal class for societal reproduction and transformation. They are between the political elites who control the allocation of economic surplus and the working class which creates the

4r. Michael D. Kennedy, "Polish Engineers' Participation in the Solidarity Movement," Social Forces 65, no. 3 (March I, 1987): 556. 42. Kennedy, "Polish Engineers," 64I. 
surplus but has little to say in its allocation...A professional alliance with a militant working class poses a serious threat to the reproduction of the status quo. ${ }^{43}$

The role of the professionals cannot be overlooked, as they added materially to the critique of the corrupt system, the goal of the workers from the start. Historiography from the later years of Solidarity also mentioned the influential role that the Catholic Church had to play. Throughout the movement's existence, it retained a close identification with the Catholic Church and the current pope, a Pole himself, John Paul II. American historian and professor of international affairs, David S. Mason, explained, in depth, the importance of this alliance: "Some people joined Solidarity precisely because of its cooperation with the Church, and some 43 percent of the members listed this as one of their reasons for joining Solidarity." ${ }^{44}$ The Catholic Church, like the Polish workers, saw their ways of life to be increasingly inconsistent with the Communist Party. They supported the workers as the vehicle for the change they desired, an alliance not typically seen, but all the more powerful.

Since the ig6os, a growing tension existed between the Catholic Church and the Communist Party in Poland, largely due to the gradual reduction of intellectual freedom, which was also a problem for the intelligentsia. ${ }^{45}$

43. Kennedy, "Polish Engineers," 642.

44. David S. Mason, "Solidarity as a New Social Movement," Political Science Quarterly,IO4, no. I (Spring, I989): 54 .

45. Kevin McDermott and Matthew Stibbe,

Revolution and Resistance in Eastern Europe,
When

Solidarity

emerged, explained Poznanski, "the clergy deeply sympathized with workers, particularly because free unions strongly pressed for more religious freedom." ${ }^{\prime 6} 6$ The involvement of the Church led Solidarity to become what Mason called, "a new social movement." ${ }_{47}$ The working class saw their economic claims deepened and empowered by the causes of other groups, and thus the movement could be called "social," as opposed to singularly "economic," "political," "intellectual," or "religious." The Church's involvement added this significant component to the 'workers' rights uprising' rhetoric of earlier scholars. Solidarity could bring increased feelings of freedom and liberty, in addition to economic stability. The Catholic Church became involved with Solidarity primarily because they were concerned not only with politics and economics, but with issues of the quality of life, equality, individual self-realization, and human rights. ${ }^{4}$

\section{CONCLUSION}

At the Twenty-Fifth Anniversary Celebration of Solidarity in Poland, Lech Wałęsa, the once ordinary working man that became the leader of Solidarity and Poland's first president, addressed the Parliament: "We hold our heads high, despite the price we have paid, because freedom is priceless." ${ }^{49}$ The Polish Solidarity

(Oxford: Berg, 2006), г20.

46. Poznanski, "Economic Adjustment," 479.

47. Mason, "Solidarity," 50.

48. Mason, "Solidarity," 5I.

49. Matthew Day, "Freedom is Priceless,

Wałęsa tells Poland," The Telegraph, August 30, 2005, accessed November 3, 20II, http://www. telegraph.co.uk/news/worldnews/europe/ poland/I497259/Freedom-is-priceless-Wałęsa- 
Movement was arguably one of the largest and most effective nonviolent protests against Communism to occur during the Cold War. A response to the gradual decay of the Polish economy, it emerged and developed into one of the largest social movements in history. This unity of Poland's people would lead to the evolution of a "Soviet sphere" country into a semi-democratic society. When examining the historiography of this movement, one can see similarities and differences of the story from beginning to end. In Solidarity's initial years, an overwhelming number of analyses about this movement emerged. Though they examined different aspects, they exhibit a consistent theme: Solidarity was first and foremost a workers' struggle. The movement was primarily due to the economic hardships felt by the majority of the Polish population at the end of the rg7os. The workers, heroic, determined, and frustrated with economic injustice, were able to band together and achieve the change in Poland.

When examining historiography from the later years, the initial message is much the same: Polish people wanted change, and through their strength and determination they were able to achieve it. But here it can be seen that this success was due to the culmination of many groups, which set Solidarity apart from other reform movements. The additional support of the workers from the intelligentsia, the professionals, and the Catholic Church pushed the Solidarity's foundations beyond the material desires of the workers. In later historiographical accounts, Solidarity was described in its most literal form: Unity. The unity of peoples for the achievement of lasting change. The Election of 1989 made Poland the first Eastern bloc country in which democratically elected representatives were able to gain power, winning the majority of the Polish parliament. Solidarity's Cold War ramifications cannot be ignored; its political influence to the rest of the Eastern bloc proved crucial in the years to come as the Cold War came to a close.

tells-Poland.html. 